\title{
La «descolonización de las mentes» en el África Subsahariana: identidad y conocimiento social
}

\author{
«Decolonization of minds» in Subsaharan \\ Africa: identity and social recognition.
}

\author{
José Luis Neila Hernández
}

Resumen:

Fenómenos actuales como los «Estados fallidos», las guerras civiles y regionales de carácter étnico o las dificultades en el avance de la Unidad Africana son indicadores de la complejidad del proceso de la construcción de la identidad y las identidades en el África negra postcolonial. La construcción de las nuevas identidades nacionales y panafricanas al hilo de la descolonización se ha desenvuelto en un marco inseparable de las propias herencias autóctonas y de la experiencia de contacto con la civilización europea-occidental, que culminaría con la colonización desde la segunda mitad del siglo XIX. El camino hacia la construcción de las nuevas identidades y el peso de Occidente se suscita no solo en la esfera de la política y la economía, sino también en el propio plano cultural e intelectual. En este sentido, la descolonización y la búsqueda de unas señas de identidad y de una historia propia pasa necesariamente por la superación de la dependencia cultural e intelectual respecto a Occidente.

Palabras Clave: Relaciones internacionales. África negra, descolonización.

Profesor Titular, Universidad Autónoma de Madrid. <jlneila@hotmail.com>. 


\section{Abstract}

Present facts such, as «failing States», civil and regional wars of ethnic origin or obstacles to the advancement of African unity are indicators of the complexity of the process of building identity and identities in postcolonial Black Africa. The building of the new national and panafricanist identities after decolonization has taken place in a framework that cannot be separated from their. native legacy and contact experiences with the Western-European civilization that would lead to colonization in the second half of the nineteenth century. The road to building new identities and the weight of western world are present not only in the political and economical spheres but also at cultural and intellectual levels. Decolonization and the search of signs of identity and the rewriting of its history therefore needs to overcome cultural and intellectual dependence from the Western world.

KEY WORDs: International relations,. Black Africa, decolonization. 
José Luis Neila Hernández • La «descolonización de las mentes»...

\section{INTRODUCCIÓN}

En 1986 se publicó una colección de ensayos del escritor y ensayista keniata Ngugi Wa Thiong'o bajo el sugerente y provocativo título Decolonising the Mind. The Politics in African Literature. Influido por el pensamiento marxista de Frantz Fanon desde finales de la década de 1960, haría suyas las argumentaciones de este al reivindicar el rechazo de los patrones de la colonización cultural expresada e implícita en el lenguaje. La asunción del lenguaje del colonizador supone la aceptación y la visión del mundo del colonizador. En coherencia con estas convicciones, Ngugi Wa Thiong'o había renunciado al cristianismo, a su nombre "colonial» James Ngugi y al inglés, para comenzar a escribir en su lengua nativa gikuyu y en swahili. La descolonización de las mentes recorría su primer peldaño precisamente en la reasunción de las referencias culturales propias frente al horizonte cultural del colonizador. En modo alguno, a su juicio, era posible hacer literatura africana si esta se hacía desde las lenguas europeas.

El compromiso intelectual de Ngugi Wa Thiong'o es un gesto y un síntoma del camino por recorrer en la rehabilitación de las referencias culturales y la identidad propia en los escenarios del colonialismo europeo-occidental. La descolonización de las mentes plantea, a nuestro juicio, un problema central en la comprensión y explicación de los problemas identitarios en los espacios postcoloniales de la modernidad y en la naturaleza de las relaciones entre estas sociedades y Occidente.

A partir de estas premisas e intenciones pretendemos esbozar una aproximación al problema de la construcción de la identidad y el conocimiento social en el África subsahariana en el marco de sus relaciones históricas con Occidente y a tenor de su incardinación periférica en el sistema mundial moderno ${ }^{1}$ Intenciones que, a nuestro modo de ver, deberían llevarnos en primer término, a una valoración de la naturaleza y del caudal de imágenes y estereotipos dominantes sobre el África subsahariana en Europa y Occidente; en segundo lugar, a una contextualización en torno a la incardinación e incorporación del África subsahariana en el sistemamundo moderno/colonial desde el plano de la geocultura; y por último, a las implicaciones que desde el prisma de la epistemología de la dominación occidental ha tenido esta relación asimétrica con el África subsahariana en la problemática de la construcción de la identidad desde el plano del pensamiento social y el uso de las lenguas.

1 Muchas de estas cuestiones tuve la ocasión y la fortuna de plantearlas y discutirlas con otros colegas y estudiantes en noviembre de 2008 en el marco del Diploma de postítulo en Estudios Internacionales Pensar internacionalmente: nuevos enfoques sobre la agenda mundial», organizado por el Instituto de Estudios Internacionales de la Universidad de Chile. Circunstancia que quisiera aprovechar para mostrar nuevamente mi más sincera gratitud y reconocimiento. 
IMÁGENES Y PERCEPCIONES

EN TORNO AL ÁFRICA

Subsahariana en Occidente

Es incuestionable que el contacto de los europeos y de Occidente en general con el continente africano ha contribuido a generar un flujo de relaciones históricas al hilo de las cuales se ha ido forjando un caudal de imágenes y percepciones cuya proyección en la actualidad sigue teniendo una determinante influencia.

La lectura del cómic de Hergé Tintín en el Congo condensa, como es habitual en su obra, el bagaje y el eurocentrismo que ha acompañado a los europeos en su visión del mundo y su comprensión decimonónica de la historia universal. Publicado en 1930, era su segunda entrega tras la publicación de Tintín en el país de los soviets. Su elaboración estaría aún muy tutelada por su mentor, el abate Wallez -director del diario conservador belga Le Vingtième Siècle. Esta se concretaría al hilo de una visita a la colonia belga del Congo con la que se pretendía divulgar la labor de los misioneros en África. La obra mostraría una mayor madurez y documentación sobre el mundo a retratar, pero desde un evidente paternalismo colonialista (Soldevilla, 2007:17). En sus páginas se evocan: el paternalismo y la eficacia científico-técnica de los europeos frente a la pereza y la incompetencia de los «negritos»; el celo de los poderes tradicionales de contenido mágico-religioso cristalizado en la figura del «malvado hechicero» frente a la autoridad -co- lonial- del hombre blanco-europeo; el «superior» sentido de justicia con el que los europeos resuelven las disputas de los primitivos negro-africanos ${ }^{2}$; y en última instancia, una escena paradigmática de «Tintín y el cura misionero protagonista transportados por un caudaloso río en una piragua mientras los negritos reman y cantan una rítmica canción con gran satisfacción en sus rostros. La colonia al servicio del colonizador» (Niubó, 2007:80).

Estas imágenes se verían correspondidas con la acidez de la crítica marxista que emana de la obra y la propia praxis revolucionaria de Frantz Fanon, impreso en algunos de sus textos como Los condenados de la tierra y Por la revolución africana. En estas obras percutiría sobre dos poderosas imágenes que han acompañado en el bagaje de Europa y de Occidente en su relación con el continente africano: de un lado, la identificación de las culturas tradicionales africanas con el exotismo, tan habitualmente esgrimido por los europeos para referirse a su percepción y visión de los lugares remotos y que se sustentaba sobre la convicción de la superioridad del colonizador (Fanon, 1965: 42); y de otro, el sarcasmo en torno al fracaso de la modernidad y la modernización en África, referida en este caso concreto a la construcción del Estado-nación burgués capitalista,

2 Tema de común encuentro entre los defensores del imperialismo europeo, como el director Henry Hathaway en su película Cuando muere el día (Sundown), realizada en 1941. 
José Luis Neila Hernández • La «descolonización de las mentes»...

al hablar de África como la caricatura de Europa (Fanon, 1963: 160)

\section{El exotismo de África en la percep- ción europea}

En los círculos académicos europeos y occidentales los estudios orientalistas, y en particular el africanismo, y la antropología canalizarían el interés de los europeos por el conocimiento, no siempre desinteresado, de otras culturas, literaturas y lenguas lejanas.

El haz de imágenes y percepciones que desde Europa y Occidente se tienen de África está cargado de tópicos coloniales, forjados previamente en las certezas hegemónicas de la Ilustración y, en algunos casos, desde la propia incorporación del continente a los flujos comerciales atlánticos de la trata de esclavos.

Hegel, según advierten Albert Roca y Ferrán Iniesta (Roca-Iniesta, 2006: 22), al absolutizar la razón occidental, desechaba las memorias africanas por no estar escritas, tachando a sus pueblos de «dormidos». Aquella apreciación no hacía sino justificar la inminente tutela colonial, pues desde el nacionalismo europeo un grupo que no fuera consciente de su pasado no podía construir su futuro. La historiografía y la antropología coloniales han asumido esa visión y la han transferido a buena parte de los científicos sociales actuales, con independencia de su aprecio o rechazo al colonialismo.

En este discurso oficial en torno a África -afirma Ferrán Iniesta-, Europa:
(...) percibe a África como el continente de la inmovilidad, aquel en el que la naturaleza no está humanizada y en que la humanidad forma parte insegmentada del paisaje conjunto. Aunque los hechos sean muy distintos de semejante percepción, la imagen de parálisis cultural africana ha ido ganando predicamento con el tiempo. En épocas recientes el conocimiento del discurso africano sobre la eternidad de la tradición ha permitido consolidar la idea de culturas inmóviles en una naturaleza reiterativa. El negro ha sido descrito incluso por algunos teóricos africanos como sede de la emoción y ajeno a la razón operativa y transformadora (Iniesta, 2001: 32).

Desde la perspectiva de las ciencias sociales, y en especial de la historia y de la antropología, este discurso tradicionalista permitía defender la ocupación colonial y la acción civilizadora. Sobre esta base se fue consolidando una interpretación oficial evolucionista y unilineal en virtud de la cual «los trayectos africanos habrían mostrado un ritmo más lento que los de sus vecinos septentrionales u orientales, hasta el punto de que cualquier cambio que haya podido suponer una homologación con la historia universal se hizo -y se continua haciendo- provenir de fuera del continente, desde la manipulación del hierro hasta los efectos múltiples de la cooperación internacional» (RocaIniesta, 2006: 22).

Durante la época colonial, afirma Jesús Contreras Grangillhome, «el elemento negro era solamente objeto de propiedad particular, no se le re- 
conocía, por tanto, calidad humana, y si esto llegaba raramente a suceder, era un individuo inferior que vivía en los estadios más atrasados de la historia» (Contreras Grangillhome, 1971: 22).

Otro de los tópicos que se fue forjando durante la modernidad en torno a África, junto a la inmovilidad social y cultural y ese eterno presente, es la propia noción de retraso tecnológico y la penuria productiva de las sociedades y civilizaciones negro-africanas.

Una de las peculiaridades o rarezas de las sociedades y civilizaciones al sur del Sáhara es su desaceleración tecnológica, especialmente a partir del III Milenio a.C. en relación con la cuenca mediterránea y el creciente fértil. Ya en el siglo I de nuestra era fuentes griegas se referían a la especialización en la producción de materias primas y a la tendencia a importar manufacturas las sociedades del este africano. Sería significativo, en este sentido, el escaso desarrollo de la lengua escrita o de la codificación matemática, así como la ausencia de tracción animal, tan limitadora de la dimensión del volumen comercial y de la producción agraria. Todo ello apuntaría a la reflexión en torno a un ritmo evolutivo diferente (Roca-Iniesta, 2006: 32), aspectos que convergerían en una de las extrañezas del África subsahariana, la «limitación social de la productividad». La literatura de contactos de los viajeros portugueses de finales del s. XVI y los observadores europeos y occidentales de épocas posteriores pusieron de manifiesto una actitud similar: la sorpresa inicial por la formas sociales y económicas africana dejarían paso, en última instancia, a la valoración peyorativa. Mucho antes del sistema capitalista las gentes del norte, fueran cristianos o musulmanes otorgaron un valor primordial a la economía, y sobre todo a sus aspectos tributario y mercantil. Y precisamente porque este rasgo social ha sido percibido de forma insistente por los occidentales, la ideología colonial y luego la neocolonial destacarían la improductividad africana en términos económicos: un "pecado mortal desde un ángulo de capitalismo triunfante» (Iniesta, 2001: 40).

\section{África «caricatura de Europa»}

Estos estereotipos forjados por los europeos a lo largo de la experiencia colonial acabarían siendo asumidos por las elites africanas occidentalizadas al alcanzar la independencia y afrontar la construcción del Estado postcolonial. (Campos Serrano, 2000: 40).

Un bagaje que conectará directamente con el fracaso del reto modernizador de los nuevos Estados independientes del África negra. La persistencia en África de la pobreza generalizada y las crisis políticas recurrentes apuntalan dos imágenes contradictorias en torno al Estado postcolonial: un Estado sobredimensionado y ajeno a las dinámicas locales y un Estado débil e inoperante, incapaz de hacer frente a los retos asumidos tras la independencia (Campos Serrano, 2006: 62). 
José Luis Neila Hernández • La «descolonización de las mentes»...

Conceptos recientes como el de «Estados fallidos», la «intervención humanitaria» o las crisis alimentarias pincelan algunos de los rasgos del fracaso de la modernización. Se ha hablado en algún caso de África como el continente donde se retrasa el progreso y solo progresa el retraso, e incluso en palabras de Nogie Tshibambe -en un artículo publicado en la revista África América Latina en 1995 sobre los Estados fallidos- estos procesos han conducido a África al «cuarto mundo en vías de desarrollo» o a «la chabola de la historia».

Imágenes que en su conjunto ponen de relieve que la relación Europa-África entre los siglos XVI y mediados del s. $\mathrm{XX}$, cuando periclita la experiencia colonial, ha sido globalmente negativa para esta última. Pero, como bien advierte Ferrán Iniesta, hay «que alejarse de la foto fija, atemporal, del primitivismo al mismo tiempo que se evita la historicidad estereotipada de un darwinismo social cuyo objetivo no es más que la justificación de la actual sociedad hegemónica» (Iniesta, 2001: 43).

\section{La subalternización de África en la geocultura de la modernidad euro- pea-occidental}

Abundando en el plano de la geocultura de la dominación, como marco complementario pero esencial, conjuntamente con los perfiles geopolíticos y geoeconómicos del sistema-mundo moderno/colonial, Walter D. Mignolo destaca la naturaleza del primer diseño de la modernidad ocurrido desde el siglo XVI, a partir del ímpetu del Orbis Universalis Christianus, que se consolidó con la «derrota de los moros, la expulsión de los judíos y el 'descubrimiento' de América». Se llevaría a cabo, asimismo, la relocalización de los límites geográficos y los límites de la humanidad de la cosmología cristiana al socaire de dos nociones esenciales la «pureza de sangre» y el «derecho de gentes».

Al protagonismo de españoles y portugueses de aquella primera modernidad le sucedería un nuevo diseño acaecido al hilo del protagonismo de Inglaterra y de Francia desde finales del siglo XVIII. En el camino la noción de hegemonía de la «misión cristiana» sería reemplazada por la de «misión civilizadora». El standard of civilization entró junto al surgimiento del Estado secular, con el cambio del espíritu intelectual introducido por la Ilustración. El espacio dominante en el imaginario de la etapa precedente de la expansión colonial, dejaría paso al tiempo. Este, desde finales del siglo XVIII, reordenaría la historia universal y se convertiría en esencia de la modernidad. El tiempo lineal de la historia universal se atrincheró, además, en la propia idea de la misión civilizadora: ser civilizado es ser moderno y ser moderno significa estar en el presente. En este giro, la vara de medir ya no sería la escritura sino la historia. Los pueblos "sin historia» se situaban en un tiempo anterior al presente. Así pues, la denegación de 
la coetaneidad se convirtió en una de las estrategias más poderosas para la colonialidad del poder en la subalternización de lenguas, conocimientos y culturas. Asimismo, tendría lugar un giro crucial en el imaginario del sistema-mundo moderno/colonial, de modo que si en los siglos XVI y XVII predominó el imaginario cristiano, a finales del siglo XIX se asistiría a un cambio radical, en la medida en que la «pureza de sangre» dejaría de medirse en términos religiosos y pasaría a basarse en el color de la piel. El racismo y la supremacía del hombre blanco, del «europeo», se erigiría en uno de los fundamentos del nuevo discurso hegemónico del imperialismo europeo.

En suma, Gerrit W. Gong destaca varias tendencias en los siglo XVI y XIX que consolidan la idea de civilización y la misión civilizadora:

La tendencia hacia la secularización está claramente relacionada, aunque de forma compleja, con los orígenes lejanos de las ciencias modernas, los comienzos de la idea de progreso, las primeras críticas históricas a los registros bíblicos, el descubrimiento de la verdadera naturaleza de las grandes religiones y culturas del mundo, en resumen, con muchas de las mismas influencias que contribuyeron al surgimiento de las normas de "civilización». Estas influencias pusieron en cuestión los elementos cristianos inicialmente implícitos en la identificación de la sociedad internacional con la cristiandad y contribuyeron a desplazarla hacia una norma basada en la idea más general y abstracta de «civilización» moderna.
Un elemento de la tradición cristiana que la tendencia hacia la secularización no solo mantuvo sino que intensificó fue el manifiesto de universalidad contenido en el mandato bíblico de llevar la buena nueva a todas las naciones. Las aspiraciones universalistas del cristianismo se transformaron en la idea de una civilización universal que podía progresar haciendo uso de principios científicos. El progreso hacia la civilización vendría cuando se aplicaran las leyes universales de la física, la química y la biología, a pesar de la miríada de manifestaciones superficiales de las diferentes culturas (Gong, 1984: 51).

En el caso del continente africano, Alicia Campos Serrano argumentaba que:

(...) la cosmovisión que legitimó la expansión de Europa concebía un mundo compuestos de estados occidentales que, en virtud de una sagrada misión de civilización, tenían el derecho y hasta la 'carga' moral, expresada poéticamente por Kipling, de ilustrar y disciplinar a todas aquellas poblaciones consideradas como salvajes y atrasadas. Los europeos se veían a sí mismos como agentes de una historia lineal de progreso, el último de cuyos estadios lo ocupaban las sociedades industrializadas occidentales. Esta concepción evolucionista de las culturas, que era un fenómeno relativamente reciente en la literatura europea, fue convirtiéndose en idea hegemónica. Había que integrar a África en la senda de la historia, de la que había estado 'excluida'.

El papel civilizador que Occidente se adjudicaba a sí mismo parecía consistir, en principio, en una mera transmisión de cultura: en la divulgación de las formas de conocimiento, organización política 
José Luis Neila Hernández • La «descolonización de las mentes»...

o sistemas productivos. La formulación de una sagrada misión civilizadora se plasmó desde finales del siglo XIX, en la dominación política de los africanos, y la integración de éstos en los sistemas económicos de las metrópolis. Pero entonces, el mantenimiento del orden y la estabilidad social, y la rentabilidad económica de la producción africana (...) constituyeron los objetivos primeros de aquella dominación, y a ellos se supeditaron los de occidentalización y aculturación de las poblaciones colonizadas (Campos Serrano, 2000: 17).

Desde finales del siglo XIX hasta la Segunda Guerra Mundial, la misión civilizadora en su versión europea se rehizo en torno a Estados Unidos cuando protagonizó su ascenso a potencia mundial, rearticulándose con el Destino Manifiesto. En adelante serían el «desarrollo»y la «modernización» los que tomarían el relevo a la «misión civilizadora». Esta epistemología de la dominación se pondría de manifiesto con la propia instrumentalización de las ciencias y el conocimiento social, como bien ha ilustrado Immanuel Wallerstein, a tenor del surgimiento y la naturaleza de la ciencia política, la economía y la sociología orientadas fundamentalmente hacia el Estado del mundo civilizado (moderno) y otras categorías como la antropología, para el estudio de los pueblos primitivos del mundo colonizado, y los «estudios orientales», para las grandes civilizaciones no occidentales.

La noción de "desarrollo», como concepto nodal de la modernización, polarizaría el diseño global hegemónico en el sistema-mundo moderno/colonial desde la impronta de la hegemonía norteamericana. Esta noción se presenta tras la II Guerra Mundial como un anclaje esencial del pensamiento científico social, tanto en la ciencia económica, y por añadidura de la historia económica, como en la sociología y otras ciencias sociales. Así se pondría de relieve en los trabajos de W.W. Rostow, C. Furtado, G. Myrdal o Gercheskron.

El desarrollo, en opinión de G. Rist, podría definirse como un experimento de progreso social, en el que Occidente es el líder que exporta o propone su modelo de experiencia y su éxito a otras zonas del mundo. En el caso africano, el desarrollo -de acuerdo con el estudio de Jokin Alberdi y Ana Rosa Alcaldeha reflejado resultados muy limitados, pues apenas:

(...) podemos decir que el final del colonialismo haya significado para el continente una mayor independencia política ni para la ciudadanía africana una mayor capacidad para decidir su futuro. Esto es, no sólo por la continua injerencia política y económica occidental en el continente, sino porque los proyectos nacionales y panafricanistas tampoco han supuesto en la práctica una verdadera emancipación ni apuesta por la libertad de las sociedades africanas, sino que han quedado atrapados en las luchas políticas por el control de los Estados poscoloniales ${ }^{3}$ (AlberdiAlcalde, 2006: 221-223).

3 Véanse los trabajos de Bayart, J. l'État en Afrique. La Politique du Ventre, Paris, Arthème Fayard, 1989; y Chabal, P.- J.P, Daloz, África camina. El desorden como 
En las políticas de cooperación al desarrollo en África, además de los componentes meramente geopolíticos y geoeconómicos, el elemento civilizatorio sigue siendo crucial para comprender los razonamientos de la cooperación internacional: la superioridad moral occidental, la hegemonía ideológica del capitalismo, el humanitarismo e incluso el sentimiento de culpabilidad histórica.

En este marco, ¿cuál es el pensamiento africano en torno al desarrollo y las prácticas de cooperación? Estos autores distinguen al menos tres modelos de pensamiento en el curso del último siglo y medio: el modernizador, el liberalizador y el identitario. Desde las teorías de la modernización se ha mantenido que a través de la cooperación internacional se podían facilitar la asistencia técnica y los recursos necesarios para que los países africanos pudieran acelerar su proceso de desarrollo. A diferencia del anterior, el enfoque liberalizador (la escuela dependentista, el marxismo africano o los estudios postcoloniales) sostenía que los países africanos deberían ser los protagonistas de sus propios procesos de desarrollo y se proponía una cooperación de contenido más político, orientada a apoyar los procesos revolucionarios y de lucha por la independencia. No obstante, la discrepancia entre ambos modelos de pensamiento se ha centrado más en las causas del subdesarrollo y en el camino

instrumento político, Barcelona, Bellaterra, 2000. a seguir para alcanzar los niveles de bienestar de los países del Norte que en la discusión de qué es el desarrollo, que ha seguido identificándose con el crecimiento económico, la mayor productividad, la industrialización y la capacidad de consumo. Por último, la tardía colonización y las resistencias al proceso de modernización explicarían la mayor presencia y relevancia del discurso identitario en el pensamiento africano frente al de otras tradiciones culturales. Sin embargo, el discurso identitario tampoco es único ni homogéneo. Por ejemplo, los colonizadores trataron de sistematizar la filosofía bantú con el objeto de reapropiarse de las culturas africanas para ponerlas al servicio de los intereses de las metrópolis y los poderes hegemónicos, pero el africanismo -en el que se pueden agrupar construcciones teóricas como la de la "civilización africana», la «negritud», el «panafricanismo» o la unidad cultural africana- también ha ensalzado la personalidad africana en su lucha contra el eurocentrismo. Buena parte de los líderes e intelectuales que impulsaron los procesos de independencia reclamaron la ruptura con Occidente y la reconstrucción de la historia del continente negro, tomando como base los aportes africanistas (AlberdiAlcalde, 2006: 225).

Finalmente, fueron la eficiencia y los mercados los que asumieron la dirección y situaron el desarrollo y la modernización como condición necesaria para el logro de los objetivos finales del capitalismo transnacional. Inserta esta 
José Luis Neila Hernández • La «descolonización de las mentes»...

última en el plano de la globalización, se habría producido una rearticulación de la diferencia colonial en una nueva forma de colonialidad del poder, que ya no estaría localizada en un Estadonación o un grupo de Estados-nación, sino como colonialidad global transnacional y transestatal. Tiene sentido en esta argumentación considerar el liberalismo como una nueva forma de civilización y no solo como una nueva organización económica. La globalización se convertiría así en una imagen del nuevo diseño civilizador. La fase actual de globalización tiene como objetivo último el mercado. Este objeto puede prescindir de los valores atribuidos a la civilización, ya que el objetivo de la expansión del mercado no exige la conversión de la gente al cristianismo o a la ciudadanía. Aunque los objetivos del mercado son inseparables de la ideología del desarrollo y la modernización, la cuestión es expandir el número de consumidores en todo el mundo más que moverse hacia un destino final establecido por la norma de civilización creada en una historia local -la de Europa- y proyectada como diseño global. En palabras del filósofo Bernard Stiegler estaríamos ante la prueba de la «modernización sin modernidad» (Ramoneda, 2008: 37).

La construcción del Estado-nación y el desarrollo del capitalismo, en el caso de los Estados fallidos y el problema del subdesarrollo -respectivamente-, ilustran los límites de la universalización de la modernidad. Ferrán Iniesta plantea la cuestión de modo más radical: «mi impresión es que el Estado-nación puede ir a un fracaso generalizado en el África contemporánea provocando así la primera derrota amplia del modelo occidental dominante», como se puede constatar en el Congo y Somalia. «Se trata de una crisis de historias evolutivas distintas y bruscamente entrelazadas» (Iniesta, 2001: 111).

En el plano de la identidad, afirman Albert Roca y Ferrán Iniesta, África ha mostrado una resistencia fundamental a la despersonalización que proponía el modelo de dominación occidental en las relaciones de poder: clanes, tribus, parentescos ficticios, grupos de edad y otras adscripciones han contribuido a poner nombre y apellido a cualquier relación social, incluso en el contexto de los espacios públicos postcoloniales. Es lo que los autores denominan «principio antrópico». De hecho, en los últimos años, autores de filiación afrocéntrica han dejado de considerar el principio antrópico como una rémora para empezar a contemplarlo como una de las bases de la adaptabilidad de largo recorrido de los africanos al mundo contemporáneo (Roca-Iniesta, 2006: 25-28).

Un ejemplo característico de la proyección de los prejuicios occidentales recaería en las nociones de identidad derivadas del parentesco, la lógica clánica. Esta, desde la perspectiva europeooccidental, «determina una solidaridad segmentaria y excluyente que, unida a la debilidad de los Estados africanos, haría muy difícil la generalización de cualquier idea de bien común», blo- 
queando así el cosmopolitismo necesario para alentar el gran comercio, la ciencia y cualquier otro campo de intercambio universal. Al mismo tiempo, se habría postulado que el clan, dada su cerrazón, «se habría mantenido inalterado, el eterno africano, entendido como atavismo conservador, resistencia al cambio»(Roca-Iniesta, 2006: 34).

Nada más lejos de la realidad, afirman los citados autores. La mirada histórica y etnográfica nos muestra que:

Si el clan se ha mantenido durante tanto tiempo no es por una rancia autocomplacencia, sino por su versatilidad holista. Los límites del clan ponen a sus miembros en contacto con el mundo en un sentido tan amplio que no podemos acotarlo y nos cuesta, de hecho, entenderlo. Los muertos, transformados en antepasados, son parte del clan y, a través de ellos, uno puede establecer vínculos orgánicos con una naturaleza conformada por una miríada de espíritus. Desde la lógica clánica, cualquier relación individual, entre vivos y muertos, es una relación colectiva (Roca-Iniesta, 2006: 34).

Nuestro camino nos conduce, en última instancia, a la reflexión en torno a la incardinación e implicación del África subsahariana en el sistema mundial moderno y, en particular, la subalternización de sus formas culturales a tenor de su relación asimétrica con la civilización europeo-occidental. Un marco esencial, en nuestra opinión, para el análisis del proceso y de las dificultades en la construcción de las identidades nacionales y panafricanas al trasiego de la incorporación de nuevas referencias y construcciones culturales tales como la nación, la ciudadanía o el sentimiento de pertenencia a una entidad o un proyecto panafricanista, de un lado, y la pervivencia y rehabilitación de formas tradicionales de identidad al hilo de la realidad social y cultural de naturaleza étnica, clánica e incluso las propias concepciones de poder, del otro. Sobrepasa la mera anécdota, en este sentido, la experiencia relatada por el académico y escritor catalán Alfred Bosch en un hostal en Jambiani, en la costa oriental de Zanzíbar. Allí el responsable del establecimiento le instó a que le enseñara el pasaporte y rellenase el libro de registro donde debía precisar su identidad y en cuyas páginas figuraban dos casillas en las que se preguntaba por su «nacionalidad» y la «tribu» del huésped (Bosch, 1998: 9-10).

\section{Identidad, cultura y conocimiento social en áfrica subsahariana}

Atendiendo a aspectos más explícitos de la epistemología de la dominación europea y occidental, el modo en cómo la cultura y el conocimiento han sido una proyección de las prácticas de dominación tendrían una profunda repercusión en el devenir de África en el curso del siglo XX.

La civilización como acervo legitimador de la dominación europea desde el siglo XVIII cristalizaría en el contexto de la Revolución francesa y, en concreto, en la Declaración de los Dere- 
José Luis Neila Hernández • La «descolonización de las mentes»...

chos del Hombre y del Ciudadano. La noción de la igualdad de los individuos también se trasladaría al ámbito de las culturas. La «lógica de la Ilustración y de los derechos universales del ciudadano -escribe Ferrán Iniesta- no es la del respeto a la diversidad cultural, sino a la homogeneidad del sistema dominante, en el seno del cual los individuos son unidades equiparables» (Iniesta, 2001: 58-59). En el plano africano, «el siglo de las luces para la 'intelligentsia' europea fue el peor siglo de sombras para los pueblos de África».

En esta misión "civilizadora», la «elite europea -escribía Jean-Paul Sartre en el prefacio a Los condenados de la tierra de F. Fanon- se dedicó a fabricar una élite indígena; se seleccionaron adolescentes, se les marcaron en la frente, con hierro candente, los principios de la cultura occidental (...) tras una breve estancia en la metrópoli se les regresaba a su país, falsificados». Europa «creyó en su misión: había helenizado a los asiáticos, había creado esa especie nueva, los negros grecolatinos». La burguesía nacional acabaría por asumir -como afirma F. Fanon- las estructuras mentales y de conocimiento de la metrópoli (Fanon, 1963: 163).

La dependencia de los pueblos africanos respecto de Europa y Occidente, durante y después de la colonización, no solo se plasmaría en términos políticos y económicos, sino también en el plano de la dependencia cultural. El mantenimiento de las «relaciones de subordinación con las potencias occidentales no fue solo un fenómeno de carácter estructural sino también cultural, dictado por la necesidad de las nuevas autoridades africanizadas de mantener las formas políticas y de consumo occidentales». De hecho, la "asunción de los modos de dominación y la cultura política de los europeos es uno de los factores principales que explica la posición que África ocupa hoy en el sistema internacional» (Campos Serrano, 2000: 44). De ahí la necesidad denunciada por algunos intelectuales africanos, como Ngugi Wa Thiong'o, de «descolonizar las mentes».

No obstante, conviene no menospreciar la capacidad de reacción de África frente al discurso e imposición de la modernidad. Albert Roca y Ferrán Iniesta han insistido en la resistencia a los proyectos hegemónicos de los europeos desde el siglo XIX, el diferente ritmo en su propia evolución social o los aspectos constitutivos de la negritud a que hacía referencia Senghor al analizar la «sensibilidad africana». Roca e Iniesta destacan que a diferencia de otros ámbitos geoculturales, como América u Oceanía, las poblaciones africanas «no se colapsaron» al hilo del contacto y el sometimiento respecto a los europeos desde el siglo XIX. Un siglo de dominación marca una experiencia de dependencia y aculturación bien distinta en su intensidad y duración en comparación con las experiencias de América. «Los africanos formaban parte del Viejo Mundo, pero lo hacían a su manera». En el Nuevo Mundo, el contacto con los europeos conllevó «una patente y vertiginosa desintegración de todas 
las facetas sociales, desencadenada en gran medida por la aniquilación física de poblaciones». Por el contrario, las «sociedades africanas (...) no serían colonizadas hasta finales del siglo XIX, siglos después que los 'nuevos mundos'. Hoy la inmensa mayoría de la población del continente se puede definir como indígena, sin que criollos o mestizos tengan apenas papel alguno, con la excepción relativa de Sudáfrica» (Roca-Iniesta, 2006: 25-26).

Asimismo, subrayan los citados autores, convendría tener en consideración otra realidad cultural que contribuye a destacar la singularidad africana dentro de la realidad dependiente del continente, la africanización de las influencias externas. Frente a la visión tradicional de África como una «frontera antigua, inamovible, invariable y esencial durante milenios», habrá que señalar que esas culturas siempre han sido permeables y han integrado en sus propios sistemas gran cantidad de aportaciones externas, pero seleccionadas y africanizadas. "La frontera africana nunca ha sido abatida, ni por el islam ni por la occidentalización hoy, aunque ha absorbido propuestas, transformado conceptos y readaptado técnicas». En suma:

África nunca ha estado aislada, ni por el Sáhara ni por el Índico, que han sido puertas selectivas, pero no cerradas. Se incorporó el Corán, las letras de cambio, el comercio a larga distancia y procesos urbanos de gran envergadura con enormes ciudades sahelianas; sus pueblos siempre han incorporado a gentes procedentes de culturas asiáticas o europeas: lo que nunca eliminaron fue su frontera antigua, aquella que es la base de su marcada personalidad cosmocéntrica, de su holismo y de su forma de inscribirse en el mundo (RocaIniesta, 2006: 41).

En esta dialéctica entre la modernización occidental y la africanización de las influencias exógenas, en qué medida fue determinante y hasta qué punto limitada la colonialidad del poder en el plano epistemológico en las sociedades del África subsahariana, atendiendo a tres aspectos: la ciencia y las ciencias sociales, la historiografía y la lengua como vehículo de cultura y de construcción de las identidades?

\section{La ciencia y las ciencias sociales como escenario de la colonialidad y subalternidad de África}

Las reflexiones de Frantz Fanon y de Leopold Sedar Senghor advertían de los prejuicios reinantes en torno al primitivismo y la singularidad de África. En Los condenados de la tierra, Fanon denuncia cómo este prejuicio emanado de la cultura occidental es igualmente asumido por el África del Norte -islámica- respecto del África subsahariana, en el sentido de que «el negro es impermeable a la lógica y a las ciencias.» No, desgraciadamente -prosigue Fanon- no es raro:

$$
\text { (...) que los estudiantes del África }
$$

Negra inscritos en colegios establecidos 
José Luis Neila Hernández • La «descolonización de las mentes»...

al norte de Sáhara escuchen preguntas de sus compañeros de colegio acerca de si hay casas en su país, si conocen la electricidad, si su familia practica la antropofagia» (Fanon, 1963: 148-149).

Por su lado, al caracterizar la cultura negra e indagar en el estilo negro, en el alma negra, Senghor haría hincapié en este tipo de prejuicios emanados de la aproximación hegemónica de Occidente hacia el mundo de ultramar y, en particular, hacia África. Al reflexionar sobre la sensibilidad del negro hacia la palabra y las ideas, y en especial a las «cualidades sensibles de la palabra»se refería a «las cualidades espirituales, no intelectuales, de las ideas». Se trataba, en suma, de un problema de "sensibilidad emotiva. La emoción es tan negra, como la razón, griega». El propio Senghor subrayaría que "reconozco que la sociedad negra no se ha preocupado demasiado por el desarrollo de la razón». La aportación negra al mundo del siglo $\mathrm{XX}$ se ha «realizado especialmente en los ámbitos literario y artístico» (Senghor, 1970: 27 y 36-37).

En el ámbito de la antropología, desde los estudios de B. Malinovski, la mayoría de las escuelas abordaron el estudio de las sociedades no occidentales como «residuales desde una perspectiva evolucionista de dirección única. El primitivismo sería un determinado tipo de organización en el que el marco simbólico trazaría los límites institucionales de la reiteración cultural». Estas «sociedades distintas a las de los observadores han sido normalmente consideradas o bien una etapa en la evolución unilineal de la humanidad, o bien, formas fracasadas de orientaciones culturales desbordadas y marginadas por el acierto en su despliegue de la estrategia occidental» (Iniesta, 2001: 34-35).

De acuerdo con la visión heraclitiana-calvinista, mayoritaria en Europa desde la Ilustración, de la teoría del cambio, de la transformación de la naturaleza y con ella de la sociedad como algo natural, su contraste sería muy notable en relación con la percepción de África como espacio de continuidad e inmutabilidad del ser y la sociedad. En estos planteamientos concurren tanto enfoques de autores abiertamente racistas, que han hablado de la incapacidad estructural del negro para construir culturas complejas -como Johnston- y otros, que sin expresarse así, han tratado de explicar cualquier modificación en las sociedades africanas como fruto evidente de una influencia externa, como Oliver-Fage (Iniesta, 2001: 33).

El imaginario del sistema-mundo moderno/colonial localizó la producción del conocimiento en Europa. La primera versión del occidentalismo a partir del descubrimiento del Nuevo Mundo y la posterior formulación del mismo a partir de la ascensión de Francia y Gran Bretaña a una posición hegemónica mundial, convirtieron las epistemologías no occidentales en algo que había que estudiar y describir, aunque no al mismo nivel que el legado grecorromano. La modernidad fue imaginada como el hogar de la epistemología. El papel central que las 
ciencias sociales comenzaron a jugar tras la II GM discurrió en paralelo a la configuración de los estudios de área y extendió la geopolítica de la producción del conocimiento al Atlántico Norte.

De acuerdo con estas premisas emanadas de la Ilustración merecen especial mención la percepción y los prejuicios europeos-occidentales entre progreso y tradición, al menos en dos supuestos: la cultura tradicional y las creencias religiosas.

De un lado, la Ilustración -subraya Ferrán Iniesta (Iniesta, 2001: 62-64)asociaría la civilización y el desarrollo de la ciencia a la palabra escrita. Un aspecto, por otro lado, ya evocado en el primer diseño de la modernidad. Si ya antes lo urbano se había opuesto a lo rural, y el arte y la técnica a lo natural, desde el siglo XVIII la insistencia aumentó cualitativamente. Lo propio de la civilización eran las lenguas estructuralmente complejas, como las flexivas, semíticas e indoeuropeas, y su salto urbano a la plasmación escrita, signo de historicidad y ruptura definitiva con las reiteraciones naturales.

En este marco se produciría la remodelación de África. Primero los exploradores y luego los misioneros y administradores hallaron una satisfactoria comprobación de las teorías sobre el primitivismo, sobre la ruralidad y sobre la práctica indistinción entre sociedad humana y naturaleza. La oralidad sintetizaba en el plano del pensamiento todo ese cúmulo de «imperfecciones incivilizadas». Rara vez los investigadores hablaron de historia pero sí de tradición, es decir, aquello que se transmite de forma oral, aquello que se hereda con la misma invariabilidad que un comportamiento animal se hereda por los descendientes. La tradición no era un aspecto de la historia, sino de la no-historia. En este marco interpretativo las ciencias sociales marginaron el «mundo hablado», excepto para la antropología por la misma naturaleza de su objeto de estudio.

En la misma línea se desenvolverían los prejuicios hacia la religión como parte fundamental de la tradición y la cultura tradicional en una Europa que desde el siglo XVIII comenzaba a consolidar con lentitud y de forma no uniforme el proceso de secularización. A este respecto, la experiencia histórica europea es inseparable de los marcos intelectuales en cuyo seno han evolucionado los occidentales durante los dos o tres siglos últimos para entender el mundo. El grueso de las ciencias sociales -sobre todo la sociología y la ciencia política- han concebido desde el principio «la religión como un obstáculo para el progreso" (Ellis-Ter Harr, 2008: 114). Los europeos llevaron a África esta concepción con sus correspondientes instituciones. Una de las principales consecuencias del gobierno colonial fue la creación de sistemas políticos laicos y burocráticos a nivel nacional, casi siempre sin precedentes en aquellos lugares.

En un plano puramente epistemológico, Albert Roca y Ferrán Iniesta advierten de la sustancial diferencia entre Europa-Occidente y el África 
José Luis Neila Hernández • La «descolonización de las mentes»...

subsahariana (Roca-Iniesta, 2006: 3637). Karl Popper argumentaba que la ciencia moderna era el único sistema de conocimiento que garantizaba lo que llamó el "predicamento abierto", es decir, el cuestionamiento permanente de los propios modelos en pos de la verdad. La sociedad que asume tal postura epistemológica solo se puede gobernar, en su opinión, mediante una democracia moderna. Este esquema respondía a una «de las contradicciones fundadoras de la modernidad: en el nombre de la libertad individual, se restringe el pluralismo social, cultural» La ciencia asumía una visión restringida y unitaria del mundo, la igualdad esencial de las personas era la premisa sine qua non de la democracia moderna.

Este modelo de conocimiento contrastaría vivamente con la cultura tradicional del África negra. El paradigma tradicional africano es abierto, en el sentido de que permite la existencia de diversos estilos de vida en una misma unidad de convivencia, sin tener que compartir las reglas de juego. Las dificultades que este modelo plantea para formular generalizaciones -al no hacer una distinción tajante entre sujeto-objeto- se compensaría por la facilidad con que tal esquema incorpora la realidad social a la producción de conocimiento. La epistemología plural se ha acompañado de una sociología plural, lo cual no quiere decir igualitaria. Un signo de ese pluralismo social sería la persistencia y el peso social de los marginales. Mientras que en Europa mujeres y brujos fueron apartados de la escena pública y de la toma de decisiones, en África, unas y otros formarían parte del espinazo de la sociedad, aunque su visibilidad fuera variable.

Retornado a la geocultura del sistema-mundo moderno, la conformación de las ciencias sociales en diversas áreas es una práctica directamente relacionada con la distribución del poder y los recursos y con el mantenimiento de la legitimidad de las instituciones sociales. La divisiones por áreas en las ciencias sociales derivan intelectualmente de la ideología liberal dominante en el siglo XIX que sostenía que el Estado y el mercado, la política y la economía, era dominios analíticamente separados. Pero como había muchas realidades que no cuadraban del todo en el ámbito del mercado ni en el del Estado, se las incluiría en una miscelánea residual, la sociología. Por último, dado que había pueblos fuera del ámbito del mundo civilizado -en lugares remotos y con los que era difícil comunicarse- el estudio de estos se reglamentaría a tenor de una nueva disciplina, la antropología.

La división de las ciencias sociales en áreas, argumenta Immanuel Wallerstein, es relativamente reciente (Wallerstein, 2004:170-182). En 1750 apenas se podía afirmar que existieran. Hacia 1850 todavía no había un conjunto claro de categorías que delimitaran dominios firmemente establecidos de la investigación social. Fue durante el período 18501914 cuando surgieron, prosperaron y cristalizaron nuestros límites actuales, haciéndose aún más firmes durante el período 1919-1945. Ellas reflejaban el 
espíritu de la época y se articularon a través de tres escisiones:

La primera transcurriría a tenor de la dicotomía pasado/presente. A quienes estudiaban el pasado se les llamaba «historiadores" y a quienes se preocupaban por el presente, «científicos sociales», categoría genérica que incluía a economistas, politólogos y sociólogos. A esta diferenciación se le asoció un barniz metodológico, en el que los historiadores adoptaron en general un actitud ideográfica, mientras que los científicos sociales optaban por la nomotética. Y se ofrecían, en el debate sobre la ciencia, como dos formas alternativas de búsqueda de la verdad objetiva.

Los practicantes de las ciencias sociales se consideraban a sí mismos como científicos, es decir, como los científicos naturales de la tradición newtonianocartesiana. La función del científico consistía en "verificar, en descubrir los secretos que subyacen bajo la superficie de las observaciones o creencias de la gente corriente.» Pero si se trata de descubrir secretos bajo la superficie se está necesariamente teorizando. Y si se está generalizando, lo más seguro y simple es creer en la existencia de verdades universales. Ahora bien, si existen verdades universales no importa dónde y cuándo se recojan los datos, con tal de que sean precisos, es decir, que se recojan adecuadamente y se analicen de forma rigurosamente lógica.

Su obra nos previene contra la complicidad existente entre saber y poder colonial, en los siguientes términos:
En el momento en que se dice esto (que hay verdades universales independientes del tiempo y el espacio), ya no hay diferencia entre estudiar Alemania en el presente o la India en el siglo V a.C., ya que están buscando verdades universales. Como los datos de Alemania en el presente son 5.000 veces mejores que los datos de la India en el 5000 a.C. estudiamos Alemania en el presente para llegar a nuestras generalizaciones (...) El 95\% como mínimo de los estudiosos y del trabajo académico en el período que media entre 1850 y 1914, y probablemente hasta 1945 , provenía de cinco países: Francia, Gran Bretaña, las Alemanias, Italia y Estados Unidos. Había también briznas de ese saber en otros lugares, pero en conjunto el trabajo académico no sólo provenía básicamente de esos cinco países, sino que la mayor parte de él fue producido por gente de esos países acerca de esos mismos países (Mignolo, 2004: 263).

Si se examina el origen social de los investigadores, se descubrirá que el $95 \%$ de los historiadores, sociólogos, economistas y politólogos de este período se sitúan en estos mismos cinco países. Todos ellos, desde el plano político-cultural, afrontaban en ese período una cuestión política básica: cómo responder a las demandas cada vez más atrevidas del creciente número de proletarios urbanos a raíz del considerable desarrollo industrial y de la conciencia sobre la soberanía popular.

La respuesta política fundamental a este problema en los cinco países mencionados fue el establecimiento del «Estado nacional liberal». El Estado iba a ser «nacional» en tanto conce- 
José Luis Neila Hernández • La «descolonización de las mentes»...

dería determinados derechos y exigiría determinadas lealtades al conjunto de sus ciudadanos. El Estado iba a ser «liberal» porque reconocía que su función central debía ser promover reformas graduales racionales que aliviaran las injusticias y el sufrimiento.

¿Dónde se escenificaría, entonces, la brecha pasado-presente? La orientación hacia el pasado, la historia basada en prejuicios idiográficos, era idónea para la creación de una identidad nacional. No es casual que en Alemania e Italia, los dos de más reciente integración nacional de los cinco mencionados, la historia desplazara absolutamente a las ciencias sociales en aquel período. Pero las ciencias sociales, con su orientación hacia el presente y sus prejuicios nomotéticos, eran a su vez portentosamente adaptables a la planificación política, instrumento necesario del reformismo racional.

La segunda fractura se articularía a tenor de la siguiente tríada: Estado/ mercado/sociedad civil. Esta se abriría entre las ciencias sociales nomotéticas: política, economía y sociología.

Históricamente en los países del centro hubo una primera etapa en la que los investigadores de las ciencias sociales estaban agrupados en una sola estructura, que además combinaba el interés por la investigación empírica y por la reforma social. Luego se produjo un impulso para profesionalizar su actividad, lo que significaba separar los componentes de investigación y de reforma, situando la primera exclusivamente en el marco universitario, tras lo cual se separaron en diferentes dominios diferenciados. En este contexto cada disciplina se vio en la tesitura de justificar intelectualmente su ámbito.

Es difícil olvidar hasta qué punto estas divisiones reflejaban la ideología liberal que sostenía que el Estado, el mercado y la sociedad civil eran tres pilares separados sobre los cuales se habían construido las estructuras sociales modernas.

La tercera fractura se entablaría en la dicotomía Occidente/no Occidente. Cuando las cuatro disciplinas mencionadas -historia, economía, ciencia política y sociología- se alzaron con estructuras y límites bastante claros en el período 1850-1945, su foco de investigación era en la práctica exclusivamente Occidente. Sin embargo, existía una necesidad social de estudiar el mundo más allá de Occidente. Efectivamente, el período 1850-1945 correspondió del apogeo de la expansión imperialista, y los cinco países que constituían el «núcleo de la investigación social» estaban muy implicados en esa expansión.

Si las disciplinas anteriores no eran los instrumentos adecuados para estudiar lo que quedaba fuera de Occidente, había que inventar otras formas de investigación social: la antropología y los estudios orientales.

La antropología se concibió como el estudio de pueblos diferentes de quienes los estudiaban, de los pueblos llamados «primitivos». ¿Quiénes eranestos? En este período la respuesta era obvia, la mayoría de las poblaciones humanas no blancas que vivían bajo la égida de 
los pueblos occidentales. Estos pueblos compartían algunas analogías: sus poblaciones eran pequeñas, como lo era su territorio, y su peso geopolítico era casi insignificante. Estos estudios parecían un vehículo útil para los dos tipos de occidentales que estaban en contacto continuo con tales pueblos: funcionarios coloniales, que trataban de mantener el nuevo orden social, y misioneros cristianos que trataban de convertir a los paganos.

Pero los rasgos que caracterizaban a estos pueblos primitivos no podían aplicarse a todas las áreas no occidentales: China, India, Persia o el mundo árabeislámico. Todas estas civilizaciones se convirtieron en dominio de los estudios orientales. Estos estudios se remontan a la Edad Media, cuando fueron emprendidos por monjes eruditos preocupados de cuestiones religiosas. Estos se concentraron en aprender lenguas y entender los textos religiosos clásicos de Oriente. Sus sucesores del siglo XIX no fueron monjes eruditos, pero los métodos que utilizaron no eran muy diferentes. En cierto modo, la cuestión intelectual básica que se planteaban era qué distinguía a estas otras altas civilizaciones de la occidental, esto es, por qué no habían conocido el progreso de Occidente.
¿En el plano historiográfico, de qué modo ha mediatizado la historiografía occidental la interpretación del pasado, la memoria y la identidad de los pueblos africanos?

En el plano historiográfico ya hemos hecho mención al modo en cómo el segundo diseño del sistema-mundo moderno desde el siglo XVIII se ampararía en la clave de bóveda de la civilización. El tiempo se revelaría crucial en la determinación de los distintos estadios, desde el primitivismo hasta el más evolucionado de la civilización europeooccidental. Es decir, la estrategia de la denegación de la contemporaneidad.

Resulta irónico, afirman Roca e Iniesta (Roca-Iniesta, 2006: 22) que al absolutizar la razón occidental, Hegel desechase las memorias africanas por no estar escritas, tachando a sus pueblos de «dormidos». La apreciación de Hegel no hacía sino justificar la entonces inminente tutela colonial, pues, desde el nacionalismo europeo contemporáneo, un grupo que no fuera consciente de su pasado no podía construir su futuro. «La historiografía colonial asumió esta visión y la ha traspasado, a menudo de forma imperceptible, a una buena parte de los historiadores actuales».

La articulación de la misión civilizadora como clave legitimadora de la expansión y la hegemonía europea escribiría uno de sus más ilustrativos capítulos en la expedición de Bonaparte a Egipto, a una de las cunas de la civilización. En un cautivador artí- 
José Luis Neila Hernández • La «descolonización de las mentes»...

culo María Luisa Ortega analiza este pasaje del imperialismo francés con el marco de fondo de la resemantización de la modernidad desde las claves de la Ilustración. Desde la segunda mitad del siglo XVIII se asistiría a la transformación de la geopolítica mundial por la clausura del espacio americano a las potencias europeas. La expansión europea debía "volver su mirada hacia el Viejo Mundo», lo que suponía el enfrentamiento con un espacio poblado por antiguas culturas y civilizaciones ya conocidas y la gestación de una «nueva ideología colonial e imperial» La Francia surgida del golpe de Estado del 18 de Fructidor (4 de septiembre de 1797) vería impulsada su política imperialista con el advenimiento de Talleyrand al Ministerio de Exteriores. En aquellas circunstancias este apelaba en su memoria Les avantages à retirer des colonies nouvelles dans les circonstances présentes a la necesidad de construir un nuevo imperio. El nuevo vector expansionista se canalizaría hacia Oriente y, en particular, hacia Egipto. Esta era la mejor elección en términos políticos y económicos, ya que su control pondría en peligro la posición de Gran Bretaña, la única enemiga declarada de la república, en relación con la ruta hacia la India. No obstante, como bien subraya María Luisa Ortega, la expedición de Bonaparte no se fraguó solo en el terreno de las tensiones geoestratégicas, sino que la conquista del Nilo era un sueño «largamente acariciado por Francia: los proyectos de conquista de la 'cuna de la civilización’ se habían sucedido uno tras otro desde aquél presentado por Leibniz a Luis XIV». El objetivo, en el contexto de finales del siglo XVIII, era la creación de un segundo imperio colonial, un imperio que iba a enfrentar a Francia con «Oriente» y que «requería un nuevo bagaje ideológico del que ya disponía la Francia revolucionaria». Para una nueva dominación se requería:

(...) una nueva ideología ligada a la más general de la Ilustración. La ciencia y la técnica que, a diferencia de la religión, eran universales podían convertirse en instrumentos de la civilización.

Europa había tomado conciencia de su superioridad material en relación con el resto de las culturas del mundo (...) La historia reciente de Occidente, término posiblemente utilizado por primera vez por Condorcet en su acepción moderna, podía considerarse la encarnación del desarrollo de la civilización y el progreso técnico (...) La «Gran Nación» surgida de la Revolución, investida de la misión prometeica de llevar la civilización al resto del mundo, está asentando los principios de un nuevo concepto de colonialismo e imperialismo: el nuevo espíritu colonial no se iba a caracterizar por una mera explotación económica, sino por la occidentalización del resto del mundo tras haber convertido en sinónimos «civilización» $\mathrm{y}$ «occidente» (Ortega, 1993: 26).

Bajo el influjo del colonialismo europeo-occidental los planteamientos del evolucionismo unilineal reinterpretarían el diferente ritmo evolutivo del continente africano en términos de retraso respecto de otras civilizaciones vecinas, hasta el punto de que los intentos 
por homologar su historia con la historia universal se hizo provenir de fuera del continente, desde la manipulación del hierro hasta los efectos múltiples de la cooperación internacional.

El aparato propagandístico del poder colonial, manifiesto no solo en la administración de los territorios dependientes sino también en el propio sistema educativo de los mismos, muestra con crudeza la práctica de la aculturación y la puesta en escena de la epistemología de la dominación. En el caso particular del imperio colonial francés, Leopold Sedar Senghor hacía mención a la reacción generada tras la independencia frente a la práctica de la enseñanza de las autoridades francesas, y en particular de la historia. La reacción frente a «nuestros antepasados los galos» (Senghor, 1970: 20)

Desde el primer tercio del siglo XIX hasta la década de 1960 en las colonias africanas, y en particular en Senegal -caso que es objeto de estudio por Marc Ferro- se impartía en su integridad la historia de Francia. Obviamente esto era así para los alumnos blancos, pero también para los alumnos negros que se iban integrando en el sistema. Si hubo algún intento de incluir un poco de historia y de geografía de África negra en los estudios fue en reducidas dosis y «siempre se le abordaba a regañadientes». En la enseñanza de la historia y en general en todo el programa educativo, no era solo la historia de Francia lo que se enseñaba, sino el poderío francés visto desde un punto de vista histórico como discurso legitimador del poder del colonizador. En el libro elaborado por Georges Hardy (Le chant à l'école indigène) celebraba el trabajo, el ahorro y otras virtudes francesas:

Para que nuestra África sea rica Amigo, pongámonos a trabajar, a trabajar...

En vez de dormir o charlar, vamos, Vamos a desbrozar la tierra. Antes de invitar a parientes y vecinos. Paguemos los impuestos, saldemos nuestras deudas, Apartemos algunos sacos de grano, Y podremos entonces cantar fuerte... Salud, Francia, gloria damos a tu nombre,

Te amamos como a nuestra madre,

Pues es a ti a quien debemos,

El fin de todas nuestras miserias...

La enseñanza de tipo metropolitano se convertiría en el acompañante obligado de la escolarización. En 1946, la definición de la Unión Francesa implicaba la asimilación y la transformación de los africanos en franceses. «La historia -añade Marc Ferro- es, a partir de ese momento, para todos, de la enseñanza primaria, la de Francia; en secundaria, la que lleva de Grecia a Roma, y después la historia vista desde Europa» (Ferro, 1995: 53). El colono hace la historia, escribía Frantz Fanon, y sabe que la hace porque él es aquí la prolongación de la metrópoli, la historia que él escribe no es pues la del país despojado, sino la historia de su nación, aquella que saquea, viola y humilla. 
José Luis Neila Hernández • La «descolonización de las mentes»...

La presencia de Francia en ultramar encarna el progreso de la historia y el de la civilización. Marc Ferro, al hilo de su reflexión sobre "Nuestros antepasados los galos», relata un testimonio estremecedor de una joven senegalesa, Sow Ndeye:

¿Qué imagen conservó Sow Ndeye de esta historia? Tenía 12 años cuando ocurrió la independencia de Senegal, y entonces se encontraba en $4^{\circ}$ grado, en una escuela con mayoría de alumnos blancos.

Para ella, el pasado está formado esencialmente por los romanos, la vida de esos niños romanos que ella imaginaba al bañarse en las termas, ir al teatro y al circo. Recuerda igualmente a los galos, su país verde y frondoso, con las cuatro estaciones bien señaladas, no como en Senegal. Este tiempo pasado, refrescante y maravilloso, lo imagina como el sol de la Provenza: Au Pays Bleu fue su primer libro de lectura, cuyas imágenes interfieren con el pasado grecorromano. $\mathrm{Y}$ después aparecen Carlomagno, que fundó su escuela, y Luis XIV, quién construyó esos extraordinarios jardines y esos palacios. Ese es el espacio en el que se mueve su memoria del pasado: no intervienen ahí ni su lugar natal, ni África. No entran a escena sino mucho más tarde, dice la maestra, ya que ese pasado no era «interesante» (...) No, el pasado de África no era capaz de alimentar siquiera la imaginación de Sow Ndeye. La Historia y el sueño estaban en otra parte (Ferro, 1995: 54-55).

Uno de los desafíos de la historiografía de los pueblos africanos es la reescritura de su historia y la recuperación de su identidad y culturas propias, superando los atavismos y distorsiones inoculadas por el discurso y las estrategias de dominación política, económica y cultural de Occidente. La labor de los historiadores africanos, en sus manuales e investigaciones y a partir de la tarea desempeñada por revistas como Afrika Zamani se ha orientado a la forja de una historia descolonizada. Una tarea que, como bien afirma Ferrán Iniesta, estos intelectuales lo «hacen con términos e incluso lenguas aprendidas en universidades occidentales, pero sus vivencias producen en sí mismas conceptos diversos a los nuestros» (Iniesta, 2001: 27).

Retomando nuestro interés por Egipto, uno de los episodios más elocuentes y significativos de la reescritura de la historia de África se escenificaría con motivo de la celebración en 1974 de un coloquio de la UNESCO en El Cairo, al hilo de cual se pretendía la recuperación del Egipto antiguo para los despliegues culturales de África frente a las tesis tradicionalmente mantenidas por buena parte de la egiptología oficial. Un planteamiento teórico orientado a la tesis de la unidad cultural de África que había de servir de base cultural e histórica para legitimar los proyectos de unidad africana (Ropivia, 1994: 78-83).

Los planteamientos clásicos de la egiptología que emanaban de la Ilustración proyectan los cánones en torno a la civilización, los orígenes y la evolución de la humanidad generando un discurso legitimador y una epistemología de la subalternización de ultramar. En este 
entramado ideológico, Egipto, como una de la cunas de la civilización, no podía ser fruto sino de su origen caucasoide o camítico.

Los supuestos desde los que se articulaba el discurso «científico» de la egiptología oficial -Champollion, Mariette o Sethe- derivarían del prejuicio cultural hegemónico de un Occidente imperial que había creado un ranking de razas en el pasado esclavista y una jerarquía de culturas en un presente democrático-progresista, en los términos utilizados por Albert Roca y Ferrán Iniesta. «Si Egipto era una civilización esplendorosa, no podía ser negro; y si sus concepciones e instituciones no eran asimilables en la griega, no podía tampoco pertenecer a otra cultura viva, porque eso le daría orgullo de pasado como arma política de presente». Los egiptólogos oficiales, apoyados por los helenistas, decretaron que el milenario Kémit era el único pueblo del mundo sin parentescos culturales y sin rasgos físicos definidos (2006: 29-30).

Todo este cúmulo de despropósitos, mezcla de racismo y menosprecio cultural, ha sido desmantelado por los sucesivos volúmenes de la Atenea negra de Martin Bernal sobre la falsificación racista de la historia por los ideólogos europeos a partir del siglo XVIII.

La egiptología y el helenismo oficial están «hoy recubiertos de una gruesa pátina de afirmaciones sin fundamento $y$ de reiteraciones vulgarizadas que forman ya patrimonio de grandes sectores de la sociedad occidental. A los faraones se les piensa blancos y a los esclavos se los ve negros» (Iniesta, 2001: 54).

¿Acaso desconocían estos egiptólogos como Champollion las referencias a Kémit -literalmente "país negro»- que era el «País de Cam» del que se hablaba tardíamente en la Biblia y, como dijo Herodoto, cuyos habitantes -pese a su muy avanzado mestizaje-eran de cabello crespo y negros de piel? ¿Fueron acaso pésimos investigadores? Ciertamente serían estos preceptos ideológicos y culturales en torno a la superioridad de la civilización europea, en conjunción con sentimientos racistas, lo que les llevó a falsificar la historia y llevar hasta sus últimas consecuencias un imperialismo académico.

En la correspondencia de los hermanos Champollion sobre las razas -prosigue Ferrán Iniesta-en los frescos tumbales de Ramsés II se constataba que habían sido conscientemente mal interpretados por Jean-François. Para descubrir el negro, aplicado a Egipto no puede limitarse ni a tener la piel negra ni el cabello crespo, sino que debía ser ultraprognato, de color azabache $\mathrm{y}$, sobre todo, notoriamente horrendo (Iniesta, 2001: 53).

Visto el tema desde el África contemporánea, los trabajos de Cheik Anta Diop, Théophile Obenga o Oum Ndigi han destacado tanto la familiaridad lingüística de la lengua de los jeroglíficos con los del África negra actual como el innegable paralelismo de concepciones e incluso de instituciones políticas: la realeza divina faraónica tiene su correlato en toda la historia africana, inclu- 
José Luis Neila Hernández • La «descolonización de las mentes»...

sive en nuestros días, donde persisten un buen número de «reyes-dios». Pese a todo, los trabajos de la egiptología negra-Escuela de Dakar-siguen siendo proscritos de las bibliografías oficiales.

En suma, es imposible-afirman Roca y Iniesta-, reconstruir la historia egipcia antigua sin un buen conocimiento de las culturas negroafricanas, porque Kémit fue su mayor y más genial expresión antigua. La lengua de los egipcios, frente a las tradicionales interpretaciones que pretendían vincularlas a grupos caucasoides (teoría camítica), está emparentada genéticamente con casi todas las lenguas nilóticas y con las del grupo níger-kongo-kordofaniano. La devoción a divinidades intermedias está en todos los países subsaharianos, e incluso prácticas como la circuncisión o la ablación del clítoris son un hecho general en el continente (y nunca de origen musulmán). Las evidencias empíricas apuntan a que Kémit es el mejor referente antiguo de los pueblos negros de África.

La subalternización de la cultura y la ciencia en los pueblos del África subsahariana también se manifestaría en el impacto de las lenguas europeas-occidentales (las lenguas de los colonizadores) en detrimento de las lenguas autóctonas. Un aspecto fundamental en la construcción de la identidad y del proyecto nacional

Hacia finales del siglo XIX los límites espaciales se transformaron en límites cronológicos. A comienzos del período moderno/colonial (siglo XVI) tuvo lugar una transformación entre límites geográficos y humanos. A finales del siglo XIX, los salvajes y caníbales en el espacio se convirtieron en primitivos y exóticos orientales en el tiempo. Mientras que el siglo XVI fue escenario de un ardiente debate sobre los límites de la humanidad -en el que los principales participantes fueron De las Casas, Sepúlveda y Vitoria-, en el siglo XIX la cuestión ya no era si los primitivos orientales era humanos, sino, por el contrario, cuán lejos estaban de la etapa presente y civilizada. La negación de la coetaneidad fue el resultado final de la relocalización de los pueblos en una jerarquía cronológica más que geográfica.

La relocalización de lenguas, pueblos y conocimientos en el tiempo y no en el espacio encontró su formulación más sistemática en las Lecciones sobre la Filosofía de la historia de Hegel (1822) que permanecieron incontestadas hasta hace unos cincuenta años, cuando los intelectuales comprometidos con los movimientos de liberación y descolonización pusieron en duda sus premisas.

Retomando los argumentos de Wallerstein en la conferencia pronunciada en la Universidad de Stanford, publicado de forma resumida en Open the Social Sciences, sobre la producción del conocimiento entre 1850-1914/1945, en cuanto a que provenía en más de un $95 \%$ de cinco países: Francia, Gran Bretaña, Las Alemanias, Italia y los 
Estados Unidos, cabe señalar que en trabajos anteriores había analizado la cuestión desde la panorámica de la lengua en el mundo académico: "Cinco países, cuatro lenguas». La geopolítica de su época situaba al menos tres de esas lenguas -inglés, francés y alemán- a la par en términos de prestigio e influencia-esto es, el número de hablantes no nativos que la habían aprendido sin ser su lengua materna.

En el camino del diseño de la segunda modernidad las lenguas hegemónicas, español y portugués serían objeto de una subalternización. En un primer momento se situarían en la periferia de la modernidad noratlántica. Y en un segundo momento se volverían a devaluar por su transcendencia y presencia en el Tercer Mundo.

En el caso del español, como lengua franca de la primera modernidad, el año 1492 fue el momento en el que Nebrija publicó la Gramática del castellano. A la reina Isabel le diría que la «lengua era el acompañante del imperio». La obra de Nebrija descansaba sobre una filosofía del lenguaje que postulaba una lengua unificada que contrarrestara la pluralidad existente. De algún modo Nebrija estaba reescribiendo el programa de Valla, esbozado en el prefacio a su Lingua latinae elegantiorum (1442). Valla se dio cuenta de que la construcción de un imperio era un objetivo que no se podía alcanzar únicamente por medio de las armas, por lo que trató de analizarlo mediante el expediente de las letras. Contrastaba el latín utilizado por sus antepasados con la expansión del Imperio romano y ponía de relieve el poder subyacente de la lengua como fuerza unificadora de las conquistas geográficas.

En la reformulación de la modernidad desde el siglo XVIII, los intelectuales románticos europeos reaccionaron contra la búsqueda de universales del lenguaje (Leibniz) y devolvieron la discusión a la región y el pueblo, anticipando una filosofía de la lengua vinculada a la política pública y a la construcción de la nación. A finales del siglo XIX fue esta filosofía la que iba a crear la fuerte convicción de que existe una relación biunívoca entre lenguas y territorios y de que hay también una relación biunívoca entre la gente que habla una determinada lengua y su identificación consigo mismos y con su territorio (Hobsbawm). La idea no era nueva ni la introdujo la filosofía de la Ilustración.

El discurso de Fitche a la nación alemana (1808) ponderaba una diferenciación entre lenguas vivas y lenguas muertas. Las lenguas muertas no eran necesariamente las que ya no se hablaban en su época, sino más bien lenguas aisladas, con tradiciones rotas y mezcladas. El francés, por ejemplo, se había separado de sus raíces latinas antes de convertirse en una lengua en sentido estricto. El inglés se convirtió en una lengua mezclada tras la conquista normanda. El alemán, por el contrario, era la única lengua a través de la cual se podía establecer un hilo continuo con el pasado hasta tiempos inmemoriales. Es sorprendente que el español o el 
José Luis Neila Hernández • La «descolonización de las mentes»...

portugués no formaran parte de las preocupaciones de Fitche. Al no ocuparse de estas lenguas, la cuestión se dirimía entre las tres lenguas de la modernidad y la expansión imperial desde el siglo XVIII que Wallerstein asociaba a la aparición de las ciencias sociales. Estas eran las lenguas del «corazón» de Europa en las lecciones de Hegel sobre historia universal, impartidas en los mismo años en que Fitche se dirigía a la nación alemana.

En el estudio realizado por Walter D. Mignolo se contabiliza un centenar de lenguas para el $95 \%$ de la población mundial en la actualidad. De ese centenar, el $75 \%$ de la población mundial habla doce. De esas doce, seis son coloniales y, por lo tanto, las lenguas de la modernidad europea. Su clasificación según el número de hablantes es la siguiente: inglés, español, alemán, portugués, francés e italiano. El chino es la lengua más hablada del planeta, por encima del inglés. Aunque este disfruta de la ventaja de haber acompañado y apoyado la localización geohistórica del capitalismo durante el período del imperio británico y en el pasado medio siglo, de Estados Unidos. El español, aunque desplazado como lengua relevante de la modernidad -dominada por el inglés, francés y alemán-, cuenta con más hablantes que estas dos últimas (Mignolo, 2003: 366 y ss) .

En cuanto a la distribución de las lenguas en el mundo por continentes, los datos ofrecidos por Walter Mignolo (p. 369) revelan lo siguente:

\begin{tabular}{|l|c|}
\hline \multicolumn{1}{|c|}{ ÁREA GEOHISTÓRICA } & LENGUAS \\
\hline Europa & $1,5 \%$ \\
\hline Oriente Medio & $1,5 \%$ \\
\hline África & $31 \%$ \\
\hline Asia & $30 \%$ \\
\hline América & $16 \%$ \\
\hline Oceanía & $20 \%$ \\
\hline
\end{tabular}

La globalización y la puesta en vigor de la misión civilizadora mediante el dispositivo de las lenguas coloniales posibilitó a estas ser habladas muy lejos de su lugar de origen. Así, la desconexión entre lenguas y territorios, la política de dos caras de las lenguas -una para la nación, otra para las colonias- y, finalmente, el incremento de las migraciones masivas posibilitadas por la Revolución Industrial y los medios de transporte revelan los esplendores y miserias de las lenguas coloniales.

Retornando a la casuística del África subsahariana, como en el caso del África anglófona, en el África francófona la cultura y la lengua francesa son una herencia colonial. La relación entre África y la lengua francesa -afirma M. Musanyi- es reciente, en torno a un siglo, pero ha dejado un legado profundo, complejo y problemático. Para comprender la subalternización cultural son muy importante comprender las condiciones históricas y las circunstancias sociales y psicológicas en que se fue con implantando la cultura y las lenguas francesas y su propia evolución hasta la actualidad. El hecho más sintomático de dicha influencia es que una veintena de Estados han optado por hacer de la lengua francesa su lengua 
oficial, lo que implica que es la lengua de la administración, de la justicia, de la gran prensa y los medios de comunicación y de la enseñanza a todos los niveles. En otros casos se ha optado por la cooficialidad con otras lenguas autóctonas (Musanyi, 2008: 32).

Desde la experiencia del colonizado se plantea el dilema de la cohabitación con la lengua del colonizador en la medida en que determinan su preocupación y sus estrategias en torno al desarrollo y la modernización, pero también y de forma muy esencial a su propia identidad cultural.

Las elites occidentalizadas, en este caso las del africanismo francés -en torno al proyecto de la negritud- asumirían el francés como vehículo de modernización, de acceso a la cultura europea y como elemento de su proyecto de emancipación. En este sentido, el ejemplo más representativo sería el del propio Leopold Sedar Senghor, quien insertaría su filiación en la cultura y la lengua francesas como parte integrante de su concepción cultural del mestizaje, parte misma de su propia experiencia vital como africano y afrancesado.

Superada, en primera instancia, la reacción de rechazo a todo aquello relacionado con el colonizador tras la independencia, Senghor reflexiona sobre la propia expansión del francés en África -la francofonía-y, en particular, entre las elites africanas. En su opinión, existe una razón de hecho, entre «estas elites hay muchos que piensan en francés y que hablan mejor el francés que su lengua materna, la cual, por otra parte, está llena de galicismos, al menos en las ciudades» (Senghor, 1970: 372). La lengua francesa no es, pues, una lengua extranjera ordinaria para estas elites, convirtiéndose de hecho en un instrumento fundamental para el acceso al saber, al poder y a la promoción social.

Desde la perspectiva de las elites africanas occidentalizadas en el contexto de las independencias y los Estados postcoloniales, será un instrumento capital para la construcción de los Estados-nación y de la identidad nacional. El francés, lengua oficial en muchos de estos Estados, es una lengua dominante jurídica y políticamente pero minoritaria sociológicamente -ya que en la mayoría de los casos la habla menos del $10 \%$ de la población. Un hecho agravado por los altos índices de analfabetismo y las bajas tasas de escolarización. Esta circunstancia plantea un problema pedagógico de gran envergadura ¿debe ser utilizada como vehículo exclusivo de enseñanza, sobre todo en los primeros años de escolarización?, se pregunta Musanyi. Un dilema determinado en buena medida por un objetivo político: una lengua no étnica que, en situación de plurilingüísmo -que es la regla general en la mayoría de los Estados africanos-, se manifiesta como un factor potencial de unificación nacional y de creación de una identidad nacional.

Una expectativa compleja, por cuanto el francés y su aprendizaje genera no pocas reticencias y rechazos por su componente iconográfico en torno a la explotación y los recuerdos 
José Luis Neila Hernández • La «descolonización de las mentes»...

del pasado imperial y su impronta de superioridad.

Conviene no olvidar, a este respecto, la propia naturaleza del sistema educativo colonial y el lugar de la enseñanza de la lengua francesa y las autóctonas. La enseñanza de la lengua africana -afirma Robert Cornevin- es una cuestión que ya había preocupado a las autoridades coloniales francesas desde 1817. De cualquier modo, la enseñanza se fijó en francés, salvo en las escuelas franco-musulmanas. Pero contrariamente a lo que se pudiera imaginar, serían las propias elites africanas quienes han opuesto siempre la mayor resistencia a que la enseñanza se imparta en otra lengua que no sea la francesa (Cornevin, 2008: 29-30).

Un episodio fechado en febrero de 1957 ilustraría esta realidad en el marco de la Unión Francesa. En la Asamblea de la Unión, Marcel Griaule invitó a los gobiernos a definir la situación lingüística de los territorios de ultramar con el fin de potenciar las lenguas locales por medio de los cauces de la enseñanza y fomentando la publicación de obras en lenguas autóctonas. La reacción de los consejeros africanos resultó muy significativa. El consejero de Costa de Marfil, Guirandou Ndiaye, entendía que la enseñanza en lengua vernácula debía potenciarse sin menoscabo de la enseñanza del francés, para superar las dificultades del aprendizaje del francés entre los estudiantes africanos por las limitaciones de tiempo en el propio sistema educativo. Este debate mostraba el celo de los parlamentarios africanos en torno a la enseñanza del francés.

Un hecho que contrasta vivamente con el sistema educativo impuesto por Bélgica en el Congo, donde la enseñanza de la geografía local, la historia indígena local, las nociones de higiene, etc. debía impartirse en lengua indígena. La enseñanza debía evitar que en el Congo, se creara de una clase de desnacionalizados, que pudieran ser considerados como extraños entre los medios europeos y como «sin patria» entre los medios indígenas.

La lengua francesa es también una «lengua de trabajo», en la medida en que en aquellos países en que es lengua oficial o cooficial, es la lengua de la administración, del propio sistema de justicia y un medio de comunicación nacional, interafricano e internacional. Como apuntaba Senghor, una de las ventajas del uso de la lengua francesa para los negros africanos era precisamente su capacidad de "audiencia internacional».

$Y$, es en última instancia, una «lengua de cultura, ciencia y por tanto un vehículo de desarrollo». La lengua francesa, afirma Musanyi, es percibida y concebida sobre todo como «un factor real de desarrollo en los dominios de la educación, de la ciencia, de la tecnología, de la economía y de la vida social».

En este sentido la concepción y la percepción de la lengua francesa reproduce la propia visión del colonizador y de los estándares de civilización de la modernidad europea occidental. El propio Senghor lo plasmaría en sus 
reflexiones en torno a la transcendencia de la lengua francesa para los africanos (Senghor, 1970: 372-375). Entre las razones que aducía señalaba las siguientes:

En primer término, la riqueza del vocabulario francés como lengua de ciencia. A partir del a priori de la identificación de la cultura y las lenguas africanas con la emoción, son en este sentido lenguas poéticas y, por tanto, vehículo indispensable para la expresión literaria. La «superioridad del francés» devendría por su capacidad para presentar un «vocabulario técnico y científico de una riqueza insuperable. Y, por último, una profusión de términos abstractos que faltan en nuestras lenguas».

En segundo lugar, la riqueza de la sintaxis francesa, dado que el francés es una lengua concisa, precisa y matizada. Todo ello la convierte en una lengua discursiva, que coloca cada hecho y cada argumento en su sitio justo. El francés es una lengua válida tanto para el análisis como para la síntesis. La sintaxis de la vivencia concreta, la del pensamiento abstracto. En una palabra, la sintaxis de la razón frente a la sintaxis de la emoción.

Y por último, la prosa francesa «nos ha enseñado a apoyarnos en hechos e ideas para elucidar el universo; mejor diría para expresar el mundo interior a través de la reestructuración coherente del universo».

El humanismo francés tiene al hombre como objeto de su actividad. El sello del genio francés continúa siendo la inquietud por el hombre, ya se trate del Derecho, de la Literatura, del Arte o de la Ciencia. El francés expresa siempre una moral. Lo cual le da su carácter de universalidad, que corrige su inclinación al individualismo.

Pero el camino hacia la descolonización de las mentes pasa necesariamente por la recuperación de la cultura propia por parte de los africanos tras las independencias e incluso la reescritura de su pasado utilizando lenguas coloniales -aprendidas-. Asimismo, en el contexto de recuperación de esa identidad tradicional y la concreción de un "pensamiento otro» el plano en el que se plantea la coexistencia de las lenguas occidentales en África y las autóctonas ha de suscitarse desde la lógica de la diversidad y el derecho de las gentes y de los pueblos a sus lenguas, comenzando por sus lenguas maternas, como paso previo para iniciar sobre bases razonables el diálogo con otros pueblos y afrontar la africanización de la modernidad.

\section{REFERENCIAS BIBLIOGRÁFICAS}

Alberdi, Jokin- y Ana Rosa Alcalde, (2006). «Cooperación para el desarrollo en África subsahariana: entre la ambivalencia del discurso y la complejidad de las realidades africanas", en VV.AA. África en el horizonte. Introducción a la realidad socioeconómica del África Subsahariana, Madrid, Catarata, pp. 220-252.

Bosch, Alfred, (1998). La vía africana. Viejas identidades, nuevos Estados, Barcelona, Bellaterra. 
José Luis Neila Hernández • La «descolonización de las mentes»...

Campos Serrano, Alicia, (2000). «La aparición de los estados africanos en el sistema internacional: la descolonización de África», en Peñas, Francisco José (Ed.) África en el sistema internacional. Cinco siglos de frontera, Madrid, Catarata, pp. 15-50.

Contreras Granghillhome, Jesús, (1971). El panafricanismo, evolución y perspectivas, México, Universidad Autónoma de México.

Cornevin, Robert, (2008). «Divergences coloniales sur l'enseignement du vernaculaire», en Manière du voir, n. 97, febrero-marzo, pp. 29-30.

Ellis, Stephen- y Gerrie Ter Haar, (2005). Mundos de poder. Pensamiento religioso y práctica política en África, Barcelona, Bellaterra.

Fanon, Frantz Los condenados de la tierra, México, FCE, 1963.

Fanon, Frantz Por la revolución africana, México, FCE, 1965.

Ferro, Marc, (1995). Cómo se cuenta la historia a los niños del mundo entero, México, FCE.

Gong, Gerrit W. (1984). The Standard of "Civilization» in International Society, Oxford, Clarendon Press.

Iniesta, Ferrán, (2001). El planeta negro. Aproximación histórica a las culturas africanas, Madrid, Catarata,

Mignolo, Walter D. (2003). Historias locales/ diseños globales. Colonialidad, conocimientos subalternos y pensamiento fronterizo, Madrid, Akal.

Musanyi Nglasso,(2008) Mwatha «Ni 'petitnègre' ni 'petit-français'», en "Le bataille des langues", revista Manière du voir, $\mathrm{n}$. 97, Février-marzo, pp. 31-32.

Niubó, Víctor, (2007) «Las aventuras de Tintín en 22 viñetas», en Vanguardia. Grandes Temas, 03, abril, pp. 80-87.
Ortega, María Luisa, (1993). "Técnica e Imperialismo. La Aventura Egipcia de Bonaparte (1798-1802)», en Ortega, María Luisa-Elena, y Javier Alberto-Ordóñez, (eds.) Técnica e imperialismo, Madrid, Ediciones Turfán, pp. 23-48.

Ramoneda, Josep (2008) «La cultura de la crisis», en El País, 15 de noviembre.

Rist, G. El desarrollo: historia de una creencia occidental, Madrid, IUDC-UCM y la Catarata, 2002.

Roca, Albert- y F. Iniesta, (2006). «Raíces: ¿Por qué la historia es un conocimiento vital en el África del siglo XXI?", en VV.AA. África en el horizonte. Introducción a la realidad socioeconómica del África Subsahariana, Madrid, Catarata, pp. 20-54.

Ropivia, Marc-Louis, (1994). Géopolitique de l'integration en Afrique Noire, Paris, Éditions L'Harmattan.

Senghor, Leopold Sedar, (1970)Libertad, negritud y humanismo, Madrid, Tecnos.

Soldevilla, Joan Manuel, (2007). "Hergé y Tintín: vidas paralelas», en Vanguardia. Grandes Temas, 03 de abril. pp. 14-20.

Vendín Gutiérrez, J.C. (Coord.) (2004). África entre la percepción externa y el proyecto emancipador, Cuadernos Bakeaz, 64, agosto.

Wa Thiong'o, Ngugi, (1986). Descolonisign the Mind. The Politics in African Literature, London and Nairobi, James Currey.

Wallerstein, Immanuel, (2004). Capitalismo histórico y movimientos antisistémicos. Un análisis de sistemas-mundo, Madrid, Akal,.

Wallerstein, Immanuel, (2007). Geopolitica y geocultura. Ensayos sobre el moderno sistema mundial, Barcelona, Kairós. 